Thorax (1952), 7, 185.

\title{
THE FAILED THORACOPLASTY
}

BY

\author{
R. GRENVILLE-MATHERS AND H. J. TRENCHARD \\ From Harrow and Edgware Chest Clinics, Middlesex
}

(RECEIVED FOR PUBLICATION JANUARY 24, 1952)

Until a few years ago thoracoplasty was a final procedure in the treatment of pulmonary tuberculosis, and the introduction of the extra-fascial strip operation made the results of this operation appear very good. Thus Sellors (1947), reporting on 588 patients, all of whom were presumed to have a positive sputum before operation, records that $64 \%$ were doing full work and $6 \%$ light work, and, of 457 patients for whom the information was available, $84 \%$ were either sputum-negative or free of sputum. Hurford (1941) found that in 35 out of 54 thoracoplasty patients the disease was quiescent one year after operation, whereas in only seven out of another series of 44 who had refused the operation was it quiescent, and Hagn-Meincke (1950) in a late follow-up of 420 patients found that $46 \%$ were healthy compared with only $5.7 \%$ of 695 patients treated conservatively in an earlier period.

The introduction of resection in the treatment of pulmonary tuberculosis has focused more attention on the results of thoracoplasty. At present adequate comparisons between the two types of operation are not possible in this country, since the only large series of cases treated by resection has been published by the Liverpool Department of Thoracic Surgery (Bickford, Edwards, Esplen, Gifford, Mair, and Thomas, 1951), where many cases which would not be suitable for thoracoplasty are treated by resection. It does appear, however, as if resection produced a higher figure for immediate sputum conversion than a thoracoplasty, although if a thoracoplasty fails to bring about sputum conversion resection is usually still possible.

In an attempt to throw more light on this problem of how to manage the patient whose sputum is still positive following a thoracoplasty, we have investigated the results of the "failed" thoracoplasty (where sputum conversion did not result) as compared with the "successful" operation (where sputum conversion resulted), and present the results in life-table form.

The provision of a control series to these two groups is always difficult when considering a chronic disease. An untreated series does not form a satisfactory control, since there is always a strong tendency to select patients of more favourable outlook for treatment. Hurford (1941) in his series of thoracoplasty cases compared his results with those who had refused the operation. These two groups are not truly comparable, since the latter group was less co-operative, an important factor in a disease such as tuberculosis. We felt, therefore, that the only comparison possible was with a large general group who had been treated in a variety of ways.

In our thoracoplasty series we have dealt only with patients who had a positive sputum before the operation. We have, therefore, compared the results in this series with the survival rates of patients in the same age groups who were sputumpositive when diagnosed during the years 1938 to 1950 , this series of patients being compiled in exactly the same way as the series of thoracoplasty cases. The latter group was found to have a similar age distribution to the thoracoplasty group.

The method of compilation was as follows. The records in the Harrow and Edgware chest clinics of all patients treated by thoracoplasty have been studied, as have the records of all those cases with a positive sputum diagnosed between 1938 and 1950 in the Harrow Chest Clinic. Such cases comprise (1) people who were diagnosed in the two areas and are still on the clinic registers, or who have died or been classified as recovered, and (2) people who have been diagnosed elsewhere and are now living in the areas, or who died in the areas, or were classified as recovered by the clinics. Patients who have moved their homes from the areas concerned have been excluded.

The follow-up of the thoracoplasty cases is based on personal examination and uniform bacteriological tests which are either cultures of sputum or of laryngeal swabs, and for this reason we have not attempted to obtain information about patients who have left the area, owing to the possible comparative inequality of the bacteriological facilities in the areas of their present residence and to the dangers attendant on follow-up records based on evidence 
from the haphazard compilation of questionnaires. This method of compilation means that, while our series of " successful" thoracoplasties, "failed" thoracoplasties, and controls can be compared one with another, they are not necessarily comparable with a series compiled by one individual surgeon or hospital team.

Altogether 230 cases of thoracoplasty were studied. Of these 16 have been excluded from the survey, since there is no evidence that they were sputum-positive at the time of the operation. Another 13 cases were also excluded for the following reasons:

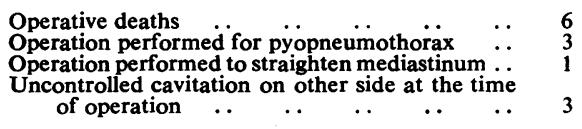

This left 201 cases for analysis. Of these 142 (80 men and 62 women) had become sputumnegative six months after operation, giving a sputum conversion rate of $71 \%$. These are classified as "successful" thoracoplasties.

The remaining 59 cases ( 30 men and 29 women) have been classified by us as having a "failed" thoracoplasty, since, although sputum conversion eventually occurred in 22 cases, this never occurred within six months of the operation and could not have resulted directly from the operation itself, although it may have assisted ultimate healing.

The majority of the operations were performed in three sanatoria of the region, the rest coming from thoracic surgical units throughout the country. The number of cases was approximately the same in each of these four groups and the rate of sputum conversion was also similar.

The age distributions of the male and female groups were comparable (Table I), as was the condition of the other lung at the time of operation (Table II). The numbers operated on in each year are given in Table III. Thoracoplasty seems more likely to be " unsuccessful" in young women,

TABLE I

age Distribution of Thoracoplasty Cases at the Time of Operation AND OF THE Control SERIES

\begin{tabular}{|c|c|c|c|c|c|}
\hline \multirow{2}{*}{\multicolumn{2}{|c|}{ Age Groups }} & \multicolumn{2}{|c|}{ Thoracoplasty Cases } & \multicolumn{2}{|c|}{ Control Cases } \\
\hline & & Men & Women & Men & Women \\
\hline $\begin{array}{l}15+ \\
20+ \\
25+ \\
30+ \\
35+ \\
40+ \\
45+\end{array}$ & \begin{tabular}{l|}
$\ldots$ \\
$\because$. \\
$\because$. \\
$\ldots$ \\
..
\end{tabular} & $\begin{array}{c}7(6 \%) \\
15(14 \%) \\
35(32 \%) \\
22(20 \%) \\
20(19 \%) \\
8(7 \%) \\
3(2 \%)\end{array}$ & $\begin{array}{c}5(5 \%) \\
12(13 \%) \\
31(33 \%) \\
17(19 \%) \\
15(16 \%) \\
7(8 \%) \\
4(4 \%)\end{array}$ & $\begin{array}{l}47(10 \%) \\
83(18 \%) \\
61(13 \%) \\
65(14 \%) \\
69(15 \%) \\
69(15 \%) \\
68(15 \%)\end{array}$ & $\begin{array}{l}42(11 \%) \\
97(26 \%) \\
83(22 \%) \\
64(17 \%) \\
50(13 \%) \\
27(7 \%) \\
14(4 \%)\end{array}$ \\
\hline \multicolumn{2}{|c|}{ Totals } & 110 & 91 & 462 & 377 \\
\hline
\end{tabular}

TABLE II

Condition of Contralateral Lung at Time of Operatig

\begin{tabular}{|c|c|c|}
\hline & Nen & Wonten \\
\hline $\begin{array}{llll}\text { No radiological lesion } & \ldots & \ldots & \ldots \\
\text { Calcified lesions only } & \ldots & \ldots & \ldots \\
\text { Stationary or regressive non-cavitating lesion } \\
\text { Lesion controlled by relaxation therapy }\end{array}$ & $\begin{array}{r}34 \\
7 \\
27 \\
42\end{array}$ & $\begin{array}{l}34^{\infty} \\
56_{0}^{\infty} \\
27 \\
\end{array}$ \\
\hline
\end{tabular}

TABLE III

ANalysis of Thoracoplasty Cases by Date

\begin{tabular}{|c|c|c|c|c|c|c|c|}
\hline $\begin{array}{r}1931 \\
32 \\
33 \\
36 \\
37 \\
38\end{array}$ & $\begin{array}{l}\because \\
\because \\
\cdots \\
\cdots \\
\cdots\end{array}$ & $\begin{array}{l}1 \\
1 \\
1 \\
1 \\
1 \\
2\end{array}$ & $\begin{array}{r}1939 \\
40 \\
41 \\
42 \\
43 \\
44\end{array}$ & $\begin{array}{l}\because \\
\because \\
\because \\
\because\end{array}$ & $\begin{array}{r}5 \\
7 \\
2 \\
16 \\
9 \\
11\end{array}$ & $\begin{array}{r}1945 \\
46 \\
47 \\
48 \\
49 \\
50\end{array}$ & $\begin{array}{l}\cdots \\
\cdots \\
\cdots \\
\cdots\end{array}$ \\
\hline
\end{tabular}

since of those who were under the age of 30 at $\overrightarrow{\text { the }}$

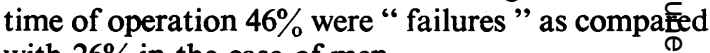
with $26 \%$ in the case of men.

At follow-up examinations the presence of raffes or crepitations on the side of the thoracoplasty was not found necessarily to indicate continged infectivity of tuberculosis, since such sounds were

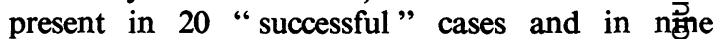
"failed" thoracoplasties.

A life table was composed for both males females, and the 3-, 5-, and 10-year survival rates are given in Table IV. Very little importance can be attached to the 10-year survival rates, since only 19 cases could have survived 10 years, but the rates are included for completeness. Seven mèn and 11 women have died, and at present 89 men amd 74 women ( $81 \%$ of the total) are well and working and 20 are alive but unfit.

TABLE IV

Survival Rates after Operation

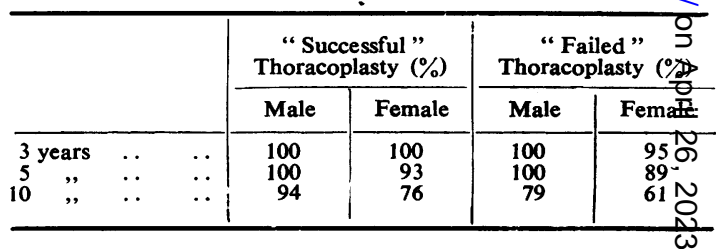

In this series of cases the " successful " operation produced better results in males than in fematess. The differences between the two groups five afd 10 years after operation is more than twice the standard error of the difference. This is in accord with the findings of Simmonds and Martin (1948, in reviewing the results of sanatorium treatment and collapse therapy, that young men did betiter than women of similar age. No such differemce was found in the group of " failed " thoracoplastios, possibly because the numbers are smaller. 
A life table composed by combining the male and female groups gives the following survival rates.

TABLE $\mathrm{V}$

Survival Rates of the Two Groups of Thoracoplasty Cases

\begin{tabular}{|c|c|c|c|}
\hline & & $\begin{array}{c}\text { "Successful " } \\
\text { Thoracoplasty (\%) }\end{array}$ & $\begin{array}{c}\text { " Failed" } \\
\text { Thoracoplasty (\%) }\end{array}$ \\
\hline $\begin{array}{l}3 \text { years } \\
5 \text { " } \\
10 \quad ",\end{array}$ & $\begin{array}{ll} & \\
\cdots & \end{array}$ & $\begin{array}{r}100 \\
96 \\
85\end{array}$ & $\begin{array}{l}98 \\
95 \\
64\end{array}$ \\
\hline
\end{tabular}

In the general control group of sputum-positive cases there were 462 males and 377 females. Cases which died within two years of diagnosis have been excluded in composing the life tables for these two groups. This, it is considered, produces a more satisfactory control series, since the average interval between diagnosis and the time of performing a thoracoplasty was 2.8 years for males and 3.8 years for females, and there is a high risk of death occurring within two years of the diagnosis of pulmonary tuberculosis. To include these deaths when comparisons are made with cases who had a thoracoplasty would not be equitable.

The survival rates for males and females three, five, and 10 years later, excluding those dying within two years, are set out in Table VI.

TABLE VI

Survival Rates for the Control Group excluding those Dying WITHIN TWO YEARS OF DIAGNOSIS

\begin{tabular}{|c|c|c|c|c|}
\hline & & & Males (\%) & Females $(\%)$ \\
\hline $\begin{array}{c}3 \text { years } \\
5 \\
10 \quad ",\end{array}$ & $\begin{array}{l}. \\
\therefore\end{array}$ & $\begin{array}{l}. . \\
\ldots\end{array}$ & $\begin{array}{l}86 \\
75 \\
57\end{array}$ & $\begin{array}{l}85 \\
74 \\
59\end{array}$ \\
\hline
\end{tabular}

There was no difference between the male and female groups, which is in keeping with the findings of other observers in this country who have calculated the survival rates from the notification registers (Cox, 1936; Tattersall, 1947; Thompson, 1943). When the thoracoplasty cases are compared with these groups, however, the male and female "successful" thoracoplasties have better survival rates at three, five, and 10 years (the difference is always more than thrice the standard error of the difference) (Table VII). The "unsuccessful" thoracoplasties have better survival rates at three and five years, but at 10 years the difference is not significant. Although the numbers are small this suggests that the early advantage of the "failed" thoracoplasty disappears as time goes on. There appears, therefore, to be a case for serious consideration of resection when it is known that a thoracoplasty has failed.

TABLE VII

The Percentage Survival of the Three Groups

\begin{tabular}{|c|c|c|c|c|c|c|}
\hline & \multicolumn{2}{|c|}{$\begin{array}{c}\text { "Successful " } \\
\text { Thoracoplasty (\%) }\end{array}$} & \multicolumn{2}{|c|}{$\begin{array}{c}\text { "Failed" } \\
\text { Thoracoplasty (\%) }\end{array}$} & \multicolumn{2}{|c|}{$\begin{array}{l}\text { Control } \\
\text { Group (\%) }\end{array}$} \\
\hline & Male & Female & Male & Female & Male & Female \\
\hline $\begin{array}{rr}3 & \text { years. } \\
5 & \Rightarrow \\
10 & \#\end{array}$ & $\begin{array}{r}100 \\
100 \\
94\end{array}$ & $\begin{array}{r}100 \\
93 \\
76\end{array}$ & $\begin{array}{r}100 \\
100 \\
79\end{array}$ & $\begin{array}{l}95 \\
89 \\
61\end{array}$ & $\begin{array}{l}86 \\
75 \\
57\end{array}$ & $\begin{array}{l}85 \\
74 \\
59\end{array}$ \\
\hline
\end{tabular}

\section{SUMMARY}

The results of 201 thoracoplasties are reviewed, the results being presented in life table form. Comparison is made with $\mathbf{4 6 2}$ male and 377 female cases who were sputum-positive when diagnosed between 1938 and 1950. The three- and five-year survival rates of both successful and failed thoracoplasties are significantly better than that of the general group of sputum-positive cases, even when those dying within two years of diagnosis are excluded. The 10-year survival rate is only better, however, in the case of successful thoracoplasties.

We wish to thank Mr. F. Ronald Edwards, F.R.C.S., for his advice and criticisms.

\section{REFERENCES}

Bickford, B. J., Edwards, F. R., Esplen, J. R., Gifford, J. H., Mair, A. M., and Thomas, O. F. (1951). Thorax, 6, 25.

Cox, G. Lissant (1936). Tuberculosis Control in England, Nat. Tuberc. Ass., New York.

Hagn-Meincke, F. (1950). J. thorac. Surg., 19, 837.

Hurford, J. V. (1941). Lancet, 1, 693.

Sellors, T. H. (1947). Thorax, 2, 216. Simmonds, F. A. H., and Martin, W. J. (1948). Amer. Rev. Tuberc.,

Tattersall, W. H. (1947). Tubercle, Lond. . 28. 85

Thompson. B. C. (1943). Brit. med. I.. 2, $7<1$. 